\title{
PEMANFAATAN KAWASAN HUTAN BAKAU SEBAGAI LOKASI PERUMAHAN DI KABUPATEN KOTABARU DI TINJAU DARI ASPEK YURIDIS
}

\author{
Kity Tokan
}

Polisi Resort Kotabaru

Kalimantan Selatan; Indonesia

Email: kitytokan@gmail.com

\begin{abstract}
The purpose of this study is to determine whether the encroachment of mangrove forests in Kotabaru District by the community is an environmental crime and to find out the sanctions that can be imposed on the perpetrators of mangrove encroachment in Kotabaru District into ponds that cause damage to the mangrove forest ecosystem. The research method used in this study is a normative juridical research method by reviewing the laws and regulations. The results of this study are that the conversion of mangroves into ponds is a criminal offense and can be subject to Article 40 paragraph (1) of Law Number 5 / 1990 concerning Conservation of Biological Resources, Law of the Republic of Indonesia Number 27 / 2007 concerning Regional Management Coastal and Small Islands, Article 98 paragraph (1) of the Law of the Republic of Indonesia Number 32 of 2009 concerning Environmental Protection and Management and Article 82 paragraph (1) of the Republic of Indonesia Law Number 18 of 2013 concerning Prevention and eradication of forest destruction .
\end{abstract}

Keywords: Criminal, Mangrove Forest, Transfer Function.

\begin{abstract}
Abstrak
Tujuan dari penelitian ini adalah untuk mengetahui apakah perambahan hutan bakau di Kabupaten Kotabaru yang dilakukan masyarakat merupakan tindak pidana lingkungan Dan untuk mengetahui sanksi yang dapat dikenakan kepada pelaku perambahan hutan bakau di Kabupaten Kotabaru menjadi tambak yang menyebabkan kerusakan terhadap ekosistem hutan bakau. Metode penelitian yang digunakan dalam penelitian ini adalah metode penelitian yuridis normatif dengan mengkaji peraturan perundang-undangan. Hasil dari penelitian ini adalah bahwa alih fungsi lahan bakau menjadi tambak adalah perbuatan pidana dan dapat dikenakan Pasal 40 ayat (1) Undang-Undang Nomor 5 Tahun 1990 Tentang Konservasi Sumber Daya Alam Hayati, Undang-Undang Republik Indonesia Nomor 27 Tahun 2007 Tentang Pengelolaan Wilayah Pesisir Dan Pulau-Pulau Kecil, Pasal 98 ayat (1) Undang-
\end{abstract}


Undang Republik Indonesia Nomor 32 tahun 2009 Tentang Perlindungan dan pengelolaan lingkungan hidup dan Pasal 82 ayat (1) Undang-Undang Republik Indonesia Nomor 18 tahun 2013 Tentang Pencegahan dan pemberantasan perusakan hutan.

Kata Kunci : Pidana, Hutan Bakau, Alih Fungsi.

\section{PENDAHULUAN}

Lingkungan hidup Indonesia yang terdiri dari aspek darat, laut dan udara merupakan ruang bagi kehidupan dalam segala aspek dan matranya dengan wawasan nusantara. Salah satu lingkungan hidup yang harus dijaga dilindungi adalah Hutan. Hutan beserta keanekaragaman hayati yang terkandung di dalamnya merupakan anugerah Tuhan Yang Maha Esa yang diamanahkan kepada bangsa Indonesia dengan harapan memerikan manfaat yang sebesar-besarnya bagi rakyat Indonesia.

Sektor kehutanan di Indonesia telah memainkan peranan penting dalam pembangunan nasional sebagai sumber terbesar perolehan devisa nonmigas, pelopor perkembangan industri, penyedia lapangan kerja, dan penggerak pembangunan daerah. Karenanya, guna mempertahankan produktivitasnya sumber daya alam ini perlu dijaga kelestariannya. ${ }^{1}$

1 Ida Ayu Pradnya Resosudarmo, 2003, Kemana Harus Melangkah, Masyarakat Hutan Dan
Bertambahnya jumlah penduduk mengakibatkan meningkatnya kebutuhan masyarakat akan sumberdaya alam dan lahan. Faktor ekonomi dan sosial budaya menjadi pendorong bagi masyarakat untuk memenuhi kebutuhan akan sumberdaya alam dan lahan. Tingginya tekanan masyarakat terhadap sumberdaya alam dalam memenuhi kebutuhan hidupnya serta pemanfaatan sumberdaya alam secara berlebihan berakibat pada rusaknya ekosistem hutan yang ada. Kerusakan ekosistem hutan yang terjadi dapat disebabkan oleh beberapa faktor seperti bencana alam, kebakaran maupun akibat dari aktifitas manusia. Beberapa aktifitas manusia yang dapat menyebabkan kerusakan ekosistem hutan antara lain pembukaan hutan untuk transmigrasi, pembakaran hutan untuk perladangan, pembalakan liar, perambahan kawasan, pertambangan liar, dan lain-lain. Rusaknya ekosistem hutan akibat dari aktifitas manusia ini telah menjadi perhatian khusus

Perumusan Kebijakan Di Indonesia, Jakarta: Yayasan Obor Indonesia, hlm. 196 
bagi pemerintah karena mengakibatkan terjadinya degradasi hutan yang tinggi.

Di Kalimantan Sendiri khususnya Kalimantan Selatan, luas kawasan mangrove diperkirakan lebih dari 100.000 hektar dan tersebar di lima kabupaten, yakni Kotabaru, Tanah Bambu, Tanah Laut, Banjar dan Barito Kuala. ${ }^{2}$ Menurut Penelitian BPDAS Barito luas Mangrove di Kalimantan Selatan yaitu: ${ }^{3}$

Tabel.1 Luas Mangrove Kalsel

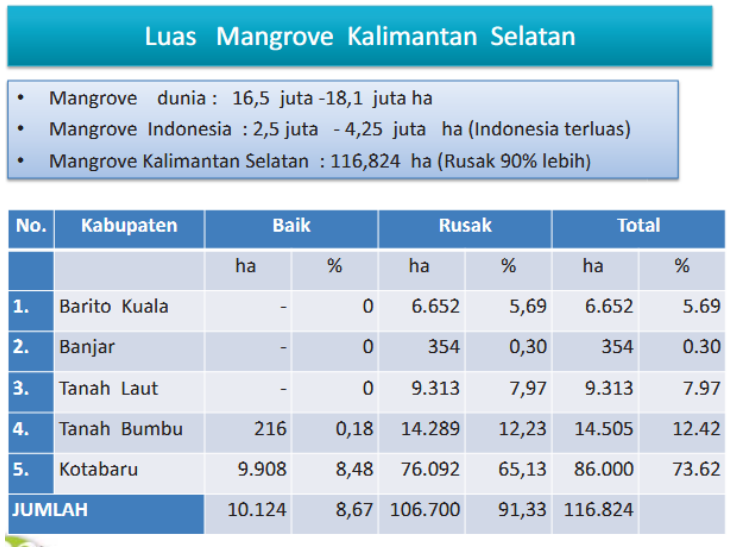

(Sumber: Ekspose Hasil Penelitian Restorasi dan

Rehabilitasi Hutan Mangrove di Kalimantan Selatan, BPK Banjarbaru)

Hutan Mangrove Di Kabupaten Kotabaru paling luas luas yaitu 86.000 ha atau sekitar 73.62 persen dari hutan mangrove di wilayah Kalimantan Selatan. Namun, Hutan Mangrove di Kabupaten

\footnotetext{
${ }^{2}$ http://sains.kompas.com/read/2011/02/21/ 1803187/Mangrove.Kalimantan.Selatan.Terancam. Diakses Tanggal 11 Oktober 2017.

${ }^{3}$ Ekspose Hasil Penelitian Restorasi dan Rehabilitasi Hutan Mangrove di Kalimantan Selatan, BPK Banjarbaru, Diakses Tanggal 11 Oktober 2017
}

Kotabaru banyak sekali rusak yaitu sekitar 76.092 atau 65.13 persen. Adapun salah satu penyebabnya dimana masyarakat Kotabaru membuka lahan dan mengalihfungsikan menjadi tambak ikan dan udang dikarenakan kebutuhan masyarakat akan lahan tambak semakin meningkat serta ketersediaan lahan semakin sempit, maka tekanan terhadap kawasan hutan bakau semakin tinggi, selain itu ada juga yang menjadikan kayunya sebagai bahan membuat rumah dan ada juga kawasan hutan tersebut dibangun pelabuhan khusus.

\section{RUMUSAN MASALAH}

Berdasarkan latar belakang sebagaimana dijelaskan diatas, penulis tertarik mengupas beberapa pemasalahan yang dijadikan objek penelitian adalah sebagai berikut :

1. Apakah perambahan hutan bakau di Kabupaten Kotabaru yang dilakukan masyarakat merupakan tindak pidana lingkungan?

2. Apakah sanksi yang dapat dikenakan kepada pelaku perambahan hutan bakau di Kabupaten Kotabaru menjadi tambak yang menyebabkan kerusakan terhadap ekosistem hutan bakau? 


\section{METODE PENELITIAN}

Jenis penelitian yang digunakan dalam penelitian mengenai Tinjauan Yuridis perambahan Hutan Bakau Di Kabupaten Kotabaru ini adalah Penelitian Hukum Normatif. Metode ini dipilih karena melakukan penelitian yang dilakukan atau ditujukan hanya pada peraturan-peraturan yang tertulis dan berlaku dalam menyikapi permasalahan pembabatan hutan bakau.

Penelitian dilakukan melalui deskripsi analisis, yaitu menggambarkan, menguraikan dan menjelaskan permasalahan mengenai Tinjauan Yuridis perambahan Hutan Bakau Di Kabupaten Kotabaru untuk kemudian dilanjutkan dengan analisis dan pembahasan untuk pemecahan permasalahan.

\section{PEMBAHASAN}

\section{Pengertian Dasar}

Lingkungan dikenal dari berbagai istilah, yaitu dalam bahasa Inggris "environment", dalam bahasa Belanda "Milleu" dan dalam bahasa Melayu "Alam Sekitar". Sedangkan secara istilah pengertian lingkungan sebagaimana yang terdapat dalam Kamus Bahasa Indonesia adalah semua yang mempengaruhi pertumbuhan manusia dan hewan ${ }^{4}$

Menurut Siti Sundari Rangkuti, mengikuti pendapat A.V. Van Den Berg bahwa pengelolaan lingkungan hidup di Indonesia berhadapan dengan hukum sebagai sarana kepentingan lingkungan yang bermacam-macam dapat dibedakan bagian-bagian hukum lingkungan, yaitu :

a. Hukum Bencana (Rampenrecht)

b. Hukum Kesehatan Lingkungan (Milieuhygienerecht)

c. Hukum Tentang Sumber Daya Alam atau Konservasi (Recht Betreffende natuurrijkdommen)

d. Hukum Tata Ruang (Recht Betreffende de verdeling van het ruimtegebruik)

e. Hukum Perlindungan Lingkungan (Milieubeschermingsrecht).

Hukum lingkungan adalah keseluruhan peraturan yang mengatur tentang tingkah laku orang tentang apa yang seharusnya dilakukan terhadap lingkungan, yang pelaksanaann peraturan tersebut dapat dipaksakan dengan suatu sanksi oleh pihak yang berwenang. ${ }^{5}$

Hukum lingkungan hidup merupakan instrumen yuridis yang memuat kaidah-kaidah tentang pengelolaan

\footnotetext{
4 Departemen Pendidikan dan Kebudayaan, 1990, Kamus Besar Bahasa Indonesia, Jakarta: Balai Pustaka, hlm.526.

5 Muhammad Erwin, 2011, Hukum Lingkungan Dalam Sistem Kebijaksanaan Pembangunan Lingkungan Hidup, Bandung:Rerlika Aditama, hlm. 9
} 
lingkungan hidup, hukum lingkungan hidup bertujuan untuk mencegah penyusutan dan kemerosotan mutu lingkungan. ${ }^{6}$ Selanjutnya dikatakan oleh Munadjat, bahwa hukum lingkungan hidup adalah konsep studi lingkungan hidup yang mengkhususkan pada ilmu hukum, dengan objek hukumnya adalah tingkat kesadaran dan pengertian masyarakat terhadap aspek perlindungan sebagai kebutuhan hidup”.

Menurut Pasal 1 angka 1 Undangundang Nomor 32 Tahun 2009 UndangUndang telah menyebutkan bahwa yang dimaksud dengan "Lingkungan Hidup" adalah kesatuan ruang dengan semua benda, daya, keadaan, dan makhluk hidup, termasuk manusia dan perilakunya, yang mempengaruhi alam itu sendiri, kelangsungan perikehidupan, dan kesejahteraan manusia serta makhluk hidup lain. Meskipun ketentuan pasal ini tidak ada memberikan penjelasan lebih lanjut maksud daripada lingkungan hidup, tetapi dapatlah dipahami bahwa lingkungan hidup tiada lain keberadaannya di bumi. Dengan dikelilingi seluruh makhluk hidup hayati maupun non hayati, tidak terkecuali manusia dengan segenap perilakunya yang berintegrasi dengan alam lingkungan hidup.

6 ST. Munadjat Danusaputro, 1985, Hukum Lingkungan Buku II, Bandung, Binacipta, hlm. 46.
Lingkungan hidup yang lazim pula dikenal dengan lingkungan alam sekitar, akan mengalami ketidakseimbangan manakala mendapat gangguan. Gangguan terhadap lingkungan hidup dapat terjadi karena 2 (dua) faktor, yakni faktor alam dan faktor perilaku manusia.

Ketidakseimbangan lingkungan hidup karena faktor alam itu sendiri tentulah tidak dapat dicegah karena merupakan takdir kehendak dari Sang Pencipta. Setidaknya manusia menghindar dari petaka tersebut jika ingin selamat. Misalnya terjadi tanah longsor, meletus gunung merapi, banjir tsunami, angin topan, angin puting beliung dan lain sebagainya. karena faktor alam maka manusia tidak berdaya apa-apa. Tetapi apabila ketidak seimbangan sebagai akibat dari ulah perbuatan manusia sehingga menimbulkan malapetaka seluruh makhluk hidup, ini berarti mengandung suatu kerugian, penderitaan dan barangkali yang lebih fatal adalah penyesalan bagi makhluk yang bernama manusia itu sendiri.

Malapetaka yang semestinya dapat dicegah dan oleh sebab itulah dibentuk peraturan tentang lingkungan hidup agar semua orang mengerti dan menghayati dalam perilaku kehidupan sehari-hari bahwa kita hidup dalam lingkungan alam yang memiliki ekosistem saling berkaitan, saling bertalian dan berhubungan antara 
satu dengan lainnya. Yang apabila salah satu mata rantai ekosistem tersebut terhambat atau rusak, maka akan rusak pulalah yang lainnya dan pada akhirnya merugikan kehidupan manusia itu sendiri.

Untuk menghindari kerusakan dan tercemarnya lingkungan hidup perlu dibentuk aturan hukum sebagai pedoman untuk pelaksanaannya yang kemudian dikenal dalam bentuk UUPPLH. Perlindungan dan pengelolaan lingkungan hidup sebagai interaksi yang harus dilakukan adalah upaya sistematis dan terpadu yang dilakukan untuk melestarikan fungsi lingkungan hidup dan mencegah terjadinya pencemaran dan/atau kerusakan lingkungan hidup yang meliputi perencanaan, pemanfaatan, pengendalian, pemeliharaan, pengawasan, dan penegakan hukum. (Pasal 1 angka 2 UUPPLH).

Selanjutnya yang dimaksud dengan pelestarian fungsi lingkungan hidup adalah rangkaian upaya untuk memelihara kelangsungan daya dukung dan daya tampung lingkungan hidup (Pasal 1 angka 6 UU. PPLH).

Untuk terlaksananya pelestarian fungsi lingkungan hidup, perlu dilakukan pengendalian terhadap pencemaran dan/atau kerusakan lingkungan hidup, yang selama ini banyak dilakukan dalam kegiatan manusia untuk memanfaatkan sumber daya lingkungan hidup. Sehingga agar jangan merugikan kehidupan manusia perlu dilakukan

pengendalian.

Pengendalian sebagaimana dimaksud dalam Pasal 13 UUPPLH, meliputi: (a) pencegahan; (b) penanggulangan, dan (c) pemulihan.

Pengendalian terhadap pencemaran dan/atau kerusakan lingkungan hidup ini harus dilakukan oleh Pemerintah, Pemerintah Daerah, dan penanggung jawab usaha dan/atau kegiatan sesuai dengan kewenangan, peran dan tanggung jawab masing-masing.

Istilah pencemaran pertama kali digunakan untuk istilah Pollution pada seminar Biologi kedua di Ciawi Bogor tahun 1970. dalam kata pencemaran terkandung arti kata pengotoran (contamination) dan pemburukan (deterioration). ${ }^{7} \quad$ Pengotoran dan pemburukan terhadap sesuatu semakin lama semakin menghancurkan setiap sasaran yang dikotori. ${ }^{8}$

Konsep tentang bahan pencemar dewasa ini telah berkembang. Pada mulanya yang dikategorikan bahan pencemar adalah bahan-bahan baru saja dalam kehidupan manusia seperti plastik, kaleng atau semacamnya. Dalam perkembangannya konsep tersebut

\footnotetext{
Soejono. D. Pengaturan Hukum Terhadap Pencemaran Lingkungan Akibat Industri, Bandung :Alumni, hlm. 10

${ }^{8}$ Ibid.hlm.10
} 
diperluas dengan batasan bahwa suatu pencemar tidak perlu bersifat baru, namun bahan/zat - zat lama (dalam arit sudah ada sejak kehidupan manusia) bisa juga dinamakan sebagai bahan pencemar bila konsentrasinya menjadi sedemikian besar sehingga mengakibatkan kerugian pada manusia.

Konsep tersebut berkembang, tidak terbatas pada suatu bahan yang bersifat materiil, tetapi suatu bentuk tingkah laku manusia yang immateriil pun bisa dikategorikan sebagai bahan pencemar, selama tingkah laku itu membahwa pada kehancuran eksistensi manusia sendiri. Manusia berusaha hidup layak dengan mengolah lingkungan alamiah menjadi lingkungan buatan yang penuh dengan kreasi baru. Oleh karena perubahan tersebut, mereka kemudian berhadapan pula dengan bahan pencemar yang akhirnya akan merugiakan mereka sendiri. ${ }^{9}$

John Salihendo mengemukakan bahwa pencemaran lingkungan hidup terdiri dari : pencemaran air, pencemaran udara, pencemaran tanah, selain itu juga pencemaran suara yang menimbulkan kebisingan. Apabila diperluas lagi, pencemaran lingkungan dapat menjangkau sampai pada benda-benda purbakala baik

9 P. Joko Subagyo. 1999, Hukum Lingkungan Masalah dan Penanggulangannya, , Jakarta : Rineka Cipta, Hlm. 27. berupa penghancuran atau hanya pencoretan-pencoretan yang tidak ada gunanya. ${ }^{10}$

Menurut Niniek Suparni, Lingkungan mempunyai kemampuan mengabsorsi limbah yang dibuang kedalamnya, kemampuan ini tidak terbatas. Apabila jumlah dan kualitas limbahnya dibuang kedalam lingkungan melampaui kemampuannya untuk mengabsorsi, maka dikatakan bahwa lingkungan ini tercemar. ${ }^{11}$

Undang-Undang Perlindungan dan Pengelolaan Lingkungan Hidup memberikan suatu pengertian bahwa yang dimaksud dengan Pencemaran lingkungan hidup adalah masuk atau dimasukkannya makhluk hidup, zat, energi, dan /atau komponen lain ke dalam lingkungan hidup oleh kegiatan manusia sehingga melampaui baku mutu lingkungan hidup yang telah ditetapkan.

Pencemaran lingkungan mengandung pengertian terjadinya penurunan kualitas lingkungan dengan adanya tolak ukur adalah esensial. Tolak ukur itu adalah baku mutu lingkungan.

Penentuan terjadinya pencemaran diukur melalui baku mutu lingkungan

${ }^{10}$ John Salihendo, 1989, Undang-Undang Gangguan dan Masalah Lingkungan, Jakarta: Sinar Grafika, hlm. 163.

11 Niniek Suparni, 1994, Pelestarian, Pengelolaan dan Peneggakkan Hukum Lingkungan, Jakarta: Sinar Grafika, hlm. 124. 
hidup sebagaimana disebutkan dalam Pasal 20 Ayat (2) UUPPLH, yang meliputi :

a. baku mutu air;

b. baku mutu air limbah;baku mutu air laut;

c. baku mutu udara ambien;

d. baku mutu emisi;

e. baku mutu gangguan, dan

f. baku mutu lain sesuai dengan perkembangan ilmu pengetahuan dan teknologi.

$$
\text { Secara umum dapat }
$$

dikatakan bahwa telah terjadi pencemaran lingkungan hidup apabila sumber daya lingkungan hidup tidak lagi berfungsi dan tidak dapat dipergunakan sebagaimana mestinya. Lebih lanjut kriteria pencemaran hanyalah ditetapkan dan dijelaskan oleh pemerintah dengan melalui Peraturan Pemerintah.

Menurut Abdurrahman, bahwa satu komponen saja dapat cukup besar pengaruhnya terhadap lingkungan hidup dan akan menjadi bahan berbahaya dan beracun yang biasa disingkat dengan "B3", yang dapat diwujudkan baik dalam bentuk bahannya sendiri maupun limbahnya ${ }^{12}$

Pencemaran lingkungan akan menimbulkan kerugian dan kerugian itu dapat terjadi dalam bentuk Kerugian ekonomi dan sosial (economic and social in jury) ataupun Gangguan sanitair (sanitary hazard).

12 Abdurrahman, 1983, Pengantar Hukum Lingkungan Indonesia, Bandung: Alumni, hlm. 46.
Menurut golongannya pencemaran itu dapat dibagi atas :

1. Kronis, dimana kerusakan terjadi secara progresif tetapi lambat

2. Kejutan atau akut; kerusakan mendadak dan berat, biasanya timbul dari kecelakaan.

3. Berbahaya; dengan kerugian biologis berat dan dalam hal ada radioaktivitas terjadi kerusakan genetis.

4. Katastrofis; disini kematian organisme hidup banyak dan mungkin organisme hidup itu menjadi punah.

Sedangkan perusakan lingkungan hidup adalah tindakan orang yang menimbulkan perubahan langsung atau tidak langsung terhadap sifat fisik, kimia, dan/atau hayati lingkungan hidup sehingga melampaui kriteria baku kerusakan lingkungan hidup.

Dalam rangka perlindungan terhadap lingkungan sumber daya alam setelah penggunaan atau pemanfaatan, maka yang demikian ini menuntut pula kepada pelaku lingkungan untuk menunaikan kewajiban melakukan pelestarian lingkungan hidup dan mewujudkan tujuan pembangunan berkelanjutan. Sebagaimana disebutkan dalam Undang-Undang ini mewajibkan kepada Pemerintah dan Pemerintah Daerah untuk membuat Kajian Lingkungan Hidup Strategis (KLHS) untuk memastikan bahwa prinsip pembangunan berkelanjutan 
telah menjadi dasar dan terintegrasi dalam pembangunan suatu wilayah dan/atau kebijakan, rencana, dan/atau program. Dengan perkataan lain, hasil KLHS harus dijadikan dasar bagi kebijakan, rencana , dan/atau program pembangunan dalam suatu wilayah.

Sebagai dasar Kajian Lingkungan Hidup Strategis (KLHS) yang selanjutnya Wajib dilaksankan oleh pemerintah, dapat ditemukan dalam Pasal 15, yang berbunyi :

(1) Pemerintah dan Pemerintah Daerah wajib membuat KLHS untuk memastikan bahwa prinsip pembangaunan berkelanjutan telah menjadi dasar dan terintegrasi dalam pembangunan suatu wilayah dan/atau kebijakan, raencana, dan/atau program.

(2) Pemerintah dan Pemerintah Daerah wajib melaksanakan KLHS sebagaimana dimaksud pada ayat (1) ke dalam penyusunan atau evaluasi:

a. rencana tata ruang wilayah (RTRW) beserta rencana rincinya, rencana pembangunan jangka panjang (RPJK), dan rencana pembangunan jangka menengah (RPJM) nasional, provinsi, dan kabupaten/kota; dan

b. kebijakan, rencana, dan/atau program yang berpotensi menimbulkan dampak dan/atau risiko lingkungan hidup.
(3) KLHS dilaksanakan dengan mekanisme:

a. pengkajian pengaruh kebijakan, rencana, dan/atau program terhadap kondisi lingkungan hidup di suatu wilayah;

b. perumusan alternatif penyempurnaan

kebijakan, rencana, dan/atau program; dan

c. rekomendasi perbaikan untuk pengambilan keputusan kebijakan, rencana, dan latau program yang mengintegrasikan prinsip pembangunan berkelanjutan.

Selanjutnya dalam Pasal 16 UU Nomor 32 Tahun 2009 tentang PPLH, disebutkan pula:

a. kapasitas daya dukung dan daya tampung lingkungan hidup untuk pembangunan;

b. perkiraan mengenai dampak dan risiko lingkungan hidup;

c. kinerja layanan/jasa ekosistem;

d. efisiensi pemanfaatan sumber daya alam;

e. tingkat kerentanan dan kapasitas adaptasi terhadap perubahan iklim;

f. tingkat ketahanan dan potensi

keanekaragaman hayati.

Kemudian yang menjadi dasar pengaturan perlindungan dan pengelolaan 
lingkungan hidup dapat pula dilihat dalam Pasal 33 Ayat (3) UUD RI Tahun 1945, dengan maksud untuk melengkapi "asas kekeluargaan" dengan prinsip kebersamaan, efisiensi berkeadilan, berkelanjutan, berwawasan lingkungan, kemandirian, serta dengan menjaga keseimbangan kemajuan dan kesatuan ekonomi nasional. Maka yang demikian itu memandang sangat penting seluruh sumber daya alam lingkungan untuk digunakan sebaik-baiknya, termasuk pula keseimbangan pelaksanaan otonomi daerah baik jangka pendek maupun jangka panjang sesuai dengan kepentingan nasional dengan menyesuaikan kebutuhan dan kearifan daerah.

Menurut W.J.S. Poerwadarminta dalam Kamus Umum Bahasa Indonesia, hutan adalah tanah yang luas yang ditumbuhi pohon-pohonan yang biasanya tidak dipelihara orang. ${ }^{13}$ Berdasarkan Terminologi Hukum Inggris-Indonesia, hutan disebut pula forest. ${ }^{14}$ Undang Undang Nomor 18 Tahun 2013 Tentang Pencegahan Dan Pemberantasan Perusakan Hutan (P3H) menjelaskan bahwa Hutan adalah suatu kesatuan ekosistem berupa hamparan lahan berisi sumber daya alam

13 W.J.S Poerwadarminta, 1994, Kamus Umum Bahasa Indonesia, Jakarta: Balai Pustaka, hlm.366.

14 Terminologi Hukum Inggris-Indonesia, 1996, Jakarta : Sinar Grafika, hlm. 293. hayati yang didominasi pepohonan dalam komunitas alam lingkungannya yang tidak dapat dipisahkan antara yang satu dan yang lainnya

Menurut pendapat Budi Riyanto dan Abimanyu Pramudya Sakti dalam tulisannya yang berjudul Kebijakan menyikapi Perdagangan Bebas di sektor Kehutanan menyebutkan bahwa: ${ }^{15}$

Hutan sebagai karunia Tuhan Yang Maha Esa merupakan modal karunia Tuhan Yang Maha Esa merupakan pembangunan nasional memiliki manfaat yang nyata bagi kehidupan dan penghidupan bangsa Indonesia, baik manfaat ekologi, sosial budaya dan ekonomi secara seimbang dan dinamis. Untuk itu hutan harus dikelola, dimanfaatkan dan dilindungi secara berkesinambungan bagi kesejahteraan masyarakat Indonesia, baik untuk generasi sekarang maupun yang akan datang.

Sumber daya alam berupa hutan mempunyai peran penting dalam penyediaan bahan baku industri sebagai sumber pendapatan, menciptakan lapangan dan kesempatan kerja. Dalam upaya meningkatkan nilai tambah serta membuka peluang kesempatan kerja dan kesempatan usaha, tiap-tiap komoditi hasil hutan dapat

\footnotetext{
${ }^{15}$ Budi Riyanto Dan Abimanyu Pramudya Sakti, Tanpa Tahun, Kebijakan Menyikapi Perdagangan Bebas Di Sektor Kehutanan, Bogor: Lembaga Pengkajian Hukum Kehutanan dan Lingkungan, Hlm. 29.
} 
diolah menjadi hasil hutan olahan yang lebih bermanfaat.

Pengelolaan sumber daya hutan di Indonesia mengacu pada ideologi penguasaan dan pemanfaatan sumber daya alam, sebagaimana tercermin dalam Pasal 33 ayat (3) Undang-Undang Dasar 1945 yang berbunyi "Negara menguasai sumber daya alam termasuk hutan dipergunakan untuk sebesar-besarnya kemakmuran rakyat".

Dalam pelaksanaan ideologi penguasaan dan pemanfaatan sumber daya hutan dijabarkan dalam beberapa peraturan perundangan antara lain Undang-Undang Nomor 5 Tahun 1990 tentang Konservasi Sumberdaya Alam Hayati dan Ekosistemnya dan Undang-Undang Nomor 14 Tahun 2009 tentang P3H Hutan beserta peraturan pelaksananya.

Penyelenggaraan kehutanan harus ditujukan untuk kepentingan rakyat sehingga benar-benar dirasakan bermanfaat dan memenuhi rasa keadilan bagi rakyat. Hal ini sebagaimana ditentukan dalam pasal 2 Pencegahan dan pemberantasan perusakan hutan yang berasaskan:

a. Keadilan dan kepastian hukum;

b. Keberlanjutan;

c. Tanggung jawab negara;

d. Partisipasi masyarakat;

e. Tanggung gugat;

f. Prioritas; dan g. Keterpaduan dan koordinasi.

Untuk itu penguasaan hutan oleh negara semata-mata untuk kemakmuran rakyat. Hal ini sebagaimana yang ditentukan pasal 4 Pencegahan dan pemberantasan perusakan hutan bertujuan:

a. menjamin kepastian hukum dan memberikan efek jera bagi pelaku perusakan hutan;

b. menjamin keberadaan hutan secara berkelanjutan dengan tetap menjaga kelestarian dan tidak merusak lingkungan serta ekosistem sekitarnya;

c. mengoptimalkan pengelolaan dan pemanfaatan hasil hutan dengan memperhatikan keseimbangan fungsi hutan guna terwujudnya masyarakat sejahtera; dan

d. meningkatnya kemampuan dan koordinasi aparat penegak hukum dan pihak-pihak terkait dalam menangani pencegahan dan pemberantasan perusakan hutan.

Menurut Kardi, dkk menyatakan bahwa hutan merupakan lapangan yang ditumbuhi pepohonan secara keseluruhan sebagai persekutuan hidup alami hayati beserta alam lingkungannya atau ekosistem. Sedangkan menurut Darjadi dan Hardjono dalam menyatakan hutan merupakan suatu kelompok pepohonan 
yang cukup luas dan cukup rapat, sehingga dapat menciptakan iklim makro sendiri. ${ }^{16}$

Menurut Wirakusumah menyatakan bahwa ekonomi sumber daya hutan adalah ilmu pengetahuan kehutanan yang mempelajari masalah-masalah ekonomi sumber daya hutan yang semakin langkah. ${ }^{17}$ Menurut Indriyanto dan Santoso menyatakan bahwa kerusakan hutan yaitu sebagian besar oleh aktivitas manusia antara lain, pembukaan lahan kebun, pembakaran hutan, dan penebangan liar. ${ }^{18}$ Menurut Setia Zain menyatakan bahwa kawasan hutan adalah wilayah-wilayah tertentu ditetapkan pemerintah untuk dipertahankan sebagai kawasan hutan tetap. ${ }^{19}$ Selanjutnya kawasan hutan wilayah-wilayah yang sudah berhutan atau yang tidak berhutan kemudian ditetapkan penguasannya bagi negara. Kawasankawasan hutan, seluruhnya merupakan wilayah-wilayah yang dalam land use planing telah/ akan ditetapkan penggunaannya di bidang kehutanan yang didasarkan pada kebutuhan serta kepentingan masyarakat Indonesia.

${ }^{16}$ Julian Wairata, 2010, Kerusakan Hutan Akibat Pembukaan Lahan Kebun Di Uncen Baru Waena Perumnas III, Makalah, Program Studi Pendidikan Geografi Jurusan Pendidikan Ilmu Pengetahuan Sosial Fakultas Keguruan Dan Ilmu Pendidikan Universitas Cenderawasih Jayapura,. Hlm. 5

$$
\begin{aligned}
& { }^{17} \mathrm{Ibid} \\
& { }^{18} \mathrm{Ibid} \\
& { }^{19} \mathrm{Ibid}
\end{aligned}
$$

Hutan Bakau adalah suatu komunitas tumbuhan atau suatu individu jenis tumbuhan yang membentuk komunitas tersebut di daerah pasang surut. ${ }^{20}$ Hutan bakau adalah tipe hutan yang secara alami dipengaruhi oleh pasang surut air laut, tergenang pada saat pasang naik dan bebas dari genangan pada saat pasang rendah. Ekosistem bakau adalah suatu sistem yang terdiri atas lingkungan biotik dan abiotik yang saling berinteraksi di dalam suatu habitat bakau. ${ }^{21}$

Sebagian ilmuwan mendefinisikan, hutan bakau adalah kelompok jenis tumbuhan yang tumbuh di sepanjang garis pantai tropis sampai sub tropis yang memiliki fungsi istimewa di suatu lingkungan yang mengandung garam dan bentuk lahan berupa pantai dengan reaksi tanah an-aerob. Sebagian lainnya mendefinisikan bahwa hutan bakau adalah tumbuhan halofit (tumbuhan yang hidup pada tempat-tempat dengan kadar garam tinggi atau bersifat alkalin) yang hidup disepanjang areal pantai yang dipengaruhi oleh pasang tertinggi sampai daerah mendekati ketinggian rata-rata air laut yang tumbuh di daerah tropis dan subtropis.

\footnotetext{
20 Novita Inka Sari W, 2011, Makalah Ekologi Pertanian, Program Studi Agroekoteknologi, Fakultas Pertanian, Malang: Universitas Brawijaya, hlm. 3

${ }^{21}$ Ibid
} 
Vegetasi bakau juga dapat menyerap dan mengurangi pencemaran (polutan). Jaringan anatomi tumbuhan bakau mampu menyerap bahan polutan, misalnya penelitian Darmiyati dkk tahun 1995 menemukan jenis Rhizophora mucronata dapat menyerap 300 ppm Mn, 20 ppm Zn, 15 ppm $\mathrm{Cu}$ dan penelitian Saefullah tahun 1995 menginformasikan pada daun Avicennia marina terdapat akumulasi $\mathrm{Pb}^{3}$ 15 ppm, $\mathrm{Cd}^{3}$ 0,5 ppm, $\mathrm{Ni}^{3} 2,4 \mathrm{ppm}^{22}$ Unsur-unsur tersebut merupakan pulutan berupa logam berat jika berada dilingkungan akan berbahaya bagi flora lain dan fauna, termasuk bagi manusia. Dengan demikian hutan mampu mereduksi polutan dari lingkungan.

Ekosistem hutan bakau memiliki produktivitas yang tinggi. Seorang peneliti, White (1987) melaporkan produktivitas primer ekosistem bakau ini sekitar 400-500 gram karbon $/ \mathrm{m}^{2} /$ tahun adalah tujuh kali lebih produktif dari ekosistem perairan pantai lainnya. ${ }^{23}$ Oleh karenanya, ekosistem bakau mampu menopang keanekaragaman jenis yang tinggi.

Vegetasi bakau memiliki adaptasi anatomi dalam merespon berbagai kondisi tempat tumbuhnya, (1) seperti adanya kelenjar garam pada golongan secreter, dan kulit yang mengelupas pada golongan nonsecreter sebagai tanggapan terhadap lingkungan yang salin, (2) system perakaran yang khas, dan lentisel debagai tanggapan terhadap tanah yang jenuh air, (3) struktur dan posisi daun yang khas sebagai tanggapan terhadap radiasi sinar matahari dan suhu yang tinggi.

\section{Perambahan Hutan Bakau Merupakan Tindak Pidana Lingkungan Hidup}

Kondisi Sumber daya alam /hutan bakau yang besar tersebut sangat mempengaruhi pola hidup masyarakatnya terutama di daerah sekitar perbatasan yang sumber penghasilannya tergantung pada hasil hutan apalagi dengan adanya keikutsertaan para pengusahanya / pemilik modal, baik yang mendukung secara finansial kegiatan tersebut untuk mencari keuntungan tanpa memperhatikan / mempertimbangkan kerusakan hutan yang dampaknya sangat kompleks bagi kehidupan manusia.

Kurangnya kesadaran masyarakat akan fungsi dan kegunaan hutan bakau di tepian laut Kabupaten Kotabaru. Sehingga masyarakat yang mengalihfungsikan area hutan bakau yang mempunyai fungsi pokok sebagai kawasan pengawetan keanekaragaman tumbuhan dan satwa menjadi area tambak ikan bandeng dan udang sejak tahun 1999 sampai dengan tahun 2017 dan merupakan mata 
pencaharian masyarakat tersebut dan banyak masyarakat yang memperjualbelikan kawasan hutan bakau untuk area tambak ikan dan udang.

Penduduk Kabupaten Kotabaru sebagian memiliki latar belakang pendidikan dan tingkat kesadaran hukum yang relatif rendah serta mayoritas bermata pencaharian sebagai petani, buruh yang tingkat ekonominya rendah dan rata-rata mereka tidak mempunyai pekerjaan tetap, kondisi yang demikian sangat memungkinkan untuk melakukan tindakan yang melawan hukum yang berlaku dengan melakukan penebangan kayu secara liar untuk memenuhi kebutuhan sehari-hari, namun tidak menutup kemungkinan bahwa para penebang kayu tersebut dibiayai oleh para pengusaha / kaum pemilik modal.

Adapun salah satu penyebabnya yaitu adanya warga yang memperjualbelikan kawasan hutan bakau dengan cara menjual surat tanah berupa segel yang dapat memudahkan masyarakat untuk mengalihfungsikan hutan bakau menjadi kawasan budi daya tambak ikan dan udang ditambah lagi lokasi hutan bakau yang jauh dari pengawasan pihak yang berwenang mempermudah pelaku membabat hutan bakau.
Perambahan hutan bakau menjadi tambak ini mengakibatkan halhal sebagai berikut :

1) Terjadinya banjir. Hal ini menyebabkan air hujan yang turun yang biasa diserap oleh pohonpohon dihutan menjadi tidak terserap karena sebagian besar hutan bakau-nya sebagai hutan penyangga rusak akibat dirambahnya hutan bakau menjadi area tambak ikan oleh warga.

2) Banyaknya habitat yang punah di kawasan hutan bakau yang merupakan kawasan lindung keanekaragaman satwa seperti bekantan, monyet dan berbagai jenis burung.

3) Nelayan setempat pun merasakan populasi ikan, kepiting, dan udang menyusut drastis. Nelayan yakin, kelangkaan hasil tangkapan nelayan dipengaruhi limbah Alam. Bakau ditebang dan dipisahkan dari kulit. Kulit bakau ini diyakini warga memicu perubahan warna air yang menjadi biru kegelapan. Perubahan itu terlihat saat air sedang surut.

Keyakinan warga cukup beralasan.

Meski kulit bakau kategori pencemaran organik, jika dibiarkan terus menerus bisa menyebabkan sedimentasi sungai. Pun, membiarkan getah larut ke air dalam jumlah besar, dapat menyebabkan kematian pada hewan air, khusus yang tidak mampu beradaptasi. Dari pelbagai kajian akademis, hutan bakau merupakan kawasan pemijahan ikan (nursery ground). Jika hutan bakau rusak, terputuslah salah satu siklus hidup ikan itu lantaran 
kehilangan lokasi pemijahan dan sumber nutrien.

Dampak yang ditimbulkan dari kerusakan ekosistem hutan khususnya hutan mangrove antara lain, dapat mengakibatkan kekeringan, dapat mengakibatkan intrusi air laut lebih jauh ke daratan, hilangnya fauna dan flora di dalamnya, dan akan menjadi sangat berbahaya apabila mengalami kepunahan yang total pada sebagian besar kawasan di Indonesia, sumber mata pencaharian penduduk setempat berkurang, dan akibat yang lebih parah lagi yaitu akan mengakibatkan banjir. Lemahnya penegakan hukum merupakan salah satu penyebab yang paling utama yang mengakibatkan terjadinya kerusakan dan punahnya ekosistem rawa yang ada. Adanya tekanan pertumbuhan jumlah penduduk yang demikian besar, yang pada akhirnya terbukti sebagai kekuatan yang paling dominan yang mengakibatkan kawasan rawa ini mengalami kepunahan.

Selain dampak kerusakan lingkungan akibat lain yang ditimbulkan dengan adanya tambak liar tersebut adalah tidak berjalannya secara maksimal tugas dan fungsi pemerintah dalam menjaga kelestarian kawasan konservasi. Kerusakan kawasan konservasi juga tidak terlepas dari kurang tegasnya pemerintah dalam menghadapi permasalahan petambak. Kegiatan tambak yang mengakibatkan kerusakan ekosistem hutan mangrove tersebut berlangsung sudah cukup lama dan sampai saat ini masih terus berlangsung. Pemerintah terkesan menahan diri untuk melakukan tindakan tegas dalam menghadapi para petambak tersebut dengan tujuan menghindari terjadinya anarkisme yang berujung pada kontak fisik. Upaya yang selama ini dilakukan masih terbatas pada kegiatan sosialisasi dan patroli pengamanan dengan harapan kerusakan hutan tidak semakin meluas.

Adanya 2 (dua) kepentingan yaitu kepentingan ekologis dan kepentingan ekonomis yang tidak berjalan secara sinergis mengakibatkan terjadinya konflik kepentingan antara pengelola kawasan konservasi dalam hal ini Balai Konservasi Sumber Daya Alam (BKSDA) Kalimantan Selatan yang mewakili kepentingan ekologis dengan para petambak yang mewakili kepentingan ekonomis.

Perambahan hutan bakau ini selain merusak hutan itu sendiri juga mencemari lingkungan hidup seperti menyebabkan banjir, dan merusak ekosistem lingkungan hidup disekitarnya seperti bekantan, burung-burung yang dilindungi serta popolasi ikan, kepiting, dan udang menyusut drastis. Dimana kelangkaan hasil tangkapan nelayan dipengaruhi limbah 
Alam. Bakau ditebang dan dipisahkan dari kulit. Kulit bakau ini diyakini warga memicu perubahan warna air yang menjadi biru kegelapan. "Perubahan itu terlihat saat air sedang surut.

Kulit bakau kategori pencemaran organik, jika dibiarkan terus menerus bisa menyebabkan sedimentasi sungai. Membiarkan getah larut ke air dalam jumlah besar, dapat menyebabkan kematian pada hewan air, khusus yang tidak mampu beradaptasi.

Perbuatan perambahan hutan bakau ini dapat merusak ekosistem dari hutan bakau tersebut. Dan ini merupakan tindak pidana perusakan ekosistem mangrove sebagaimana Pasal 35 huruf e UndangUndang Republik Indonesia Nomor 27 Tahun 2007 Tentang Pengelolaan Wilayah Pesisir Dan Pulau-Pulau Kecil:

\section{Pasal 35}

Dalam pemanfaatan Wilayah Pesisir dan Pulau-Pulau Kecil, setiap Orang secara langsung atau tidak langsung dilarang:

a. menambang terumbu karang yang menimbulkan kerusakan Ekosistem terumbu karang;

b. mengambil terumbu karang di Kawasan konservasi;

c. menggunakan bahan peledak, bahan beracun, dan/atau bahan lain yang merusak Ekosistem terumbu karang; d. menggunakan peralatan, cara, dan metode lain yang merusak Ekosistem terumbu karang;

e. menggunakan cara dan metode yang merusak Ekosistem mangrove yang tidak sesuai dengan karakteristik Wilayah Pesisir dan Pulau-Pulau Kecil;

f. melakukan konversi Ekosistem mangrove di Kawasan atau Zona budidaya yang tidak memperhitungkan keberlanjutan fungsi ekologis Pesisir dan Pulau-Pulau Kecil;

g. menebang mangrove di Kawasan konservasi untuk kegiatan industri, pemukiman, dan/atau kegiatan lain;

h. menggunakan cara dan metode yang merusak padang lamun;

i. melakukan penambangan pasir pada wilayah yang apabila secara teknis, ekologis, sosial, dan/atau budaya menimbulkan kerusakan lingkungan dan/atau pencemaran lingkungan dan/atau merugikan Masyarakat sekitarnya;

j. $\quad$ melakukan penambangan minyak dan gas pada wilayah yang apabila secara teknis, ekologis, sosial dan/atau budaya menimbulkan kerusakan lingkungan dan/atau pencemaran lingkungan dan/atau merugikan Masyarakat sekitarnya;

k. melakukan penambangan mineral pada wilayah yang apabila secara teknis dan/atau ekologis dan/atau sosial dan/atau budaya menimbulkan kerusakan lingkungan dan/atau pencemaran lingkungan dan/atau merugikan Masyarakat sekitarnya; serta 
l. melakukan pembangunan fisik yang menimbulkan kerusakan lingkungan dan/atau merugikan Masyarakat sekitarnya.

Perbuatan alihfungsi Hutan Bakau Di Kabupaten Kotabaru Provinsi Kalimantan Selatan ini yang mengakibatkan pencemaran dan perusakan lingkungan hidup merupakan tindak pidana pencemaran dan perusakan lingkungan hidup.

Pengrusakan terhadap lingkungan hidup diatur dalam Pasal 1 angka 14 Undang-undang Nomor 32 Tahun 2009 Tentang Perusakan Lingkungan Hidup adalah tindakan orang yang menimbulkan perubahan langsung atau tidak langsung terhadap sifat fisik, kimia, dan/atau hayati lingkungan hidup sehingga melampaui kriteria baku kerusakan lingkungan hidup.

Selain itu menurut Pasal 1 angka 16 Undang-Undang Republik Indonesia Nomor 18 tahun 2013 Tentang Pencegahan dan pemberantasan perusakan hutan juga merupakan pengrusakan hutan, Perusakan hutan adalah proses, cara, atau perbuatan merusak hutan melalui kegiatan pembalakan liar, penggunaan kawasan hutan tanpa izin atau penggunaan izin yang bertentangan dengan maksud dan tujuan pemberian izin di dalam kawasan hutan yang telah ditetapkan, yang telah ditunjuk, ataupun yang sedang diproses penetapannya oleh Pemerintah.

Pengertian tindak pidana kehutanan adalah suatu peristiwa yang telah/sedang/akan terjadi berupa perbuatan melanggar larangan atau kewajiban dengan ancaman sanksi pidana dalam Undangundang Nomor 18 Tahun 2013 tentang Pencegahan dan Pemberantasan Perusakan Hutan $(\mathrm{P} 3 \mathrm{H})$ bagi barangsiapa yang secara melawan hokum melanggarnya.

Penebangan liar/ pembabatan hutan bakau untuk dijadikan bahan membuat rumah atau membangun pelabuhan khusus merupakan perbuatan-perbuatan yang dapat menimbulkan kerusakan hutan bakau. Hal ini jelas-jelas telah melanggar Pasal 69 ayat 1 huruf a UUPPLH menyebutkan Setiap orang dilarang. melakukan perbuatan yang mengakibatkan pencemaran dan/atau perusakan lingkungan hidup.

Menurut Pasal 97 Undang-undang Nomor 32 Tahun 2009 Tentang Perusakan Lingkungan Hidup menyatakan bahwa Tindak pidana dalam undang-undang ini merupakan kejahatan. Berdasarkan rumusan -rumusan perusakan lingkungan hidup tersebut, maka delik perusakan lingkungan, termasuk pengrusakan hutan dapat dirumuskan sebagai berikut:

1. Perbuatan yang menimbulkan perubahan langsung atau tidak 
langsung terhadap sifat-sifat fisik dan atau hayati lingkungan sifat fisik, kimia, dan/atau hayati lingkungan hidup sehingga melampaui kriteria baku kerusakan lingkungan hidup;

2. Proses, cara, atau perbuatan merusak hutan melalui kegiatan pembalakan liar, penggunaan kawasan hutan tanpa izin atau penggunaan izin yang bertentangan dengan maksud dan tujuan pemberian izin di dalam kawasan hutan yang telah ditetapkan, yang telah ditunjuk, ataupun yang sedang diproses penetapannya oleh Pemerintah.

Adapun alih fungsi bahkan melakukan pembabatan hutan bakau di Kabupaten Kotabaru telah memenuhi kedua unsur-unsur delik tindak pidana perusakan lingkungan hidup dan Undang Undang Nomor 18 Tahun 2013 tentang Pencegahan dan Pemberantasan Perusakan Hutan (P3H).

Dimana alih fungsi di Kabupaten Kotabaru ini melalui kegiatan pembalakan liar, penggunaan kawasan hutan tanpa izin atau penggunaan izin yang bertentangan dengan maksud dan tujuan pemberian izin di dalam kawasan hutan yang telah ditetapkan, yang telah ditunjuk, ataupun yang sedang diproses penetapannya oleh Pemerintah.

Adapun pembabatan hutan bakau serta pengalihfungsian hutan bakau di menjadi areal tambak ikan dan udang oleh masyarakat walaupun pembabatan tersebut untuk keperluan masyarakat juga seperti untuk kebutuhan kayu, arang maupun areal tambak masyarakat tetapi akibat yang ditimbulkan yaitu banjir yang juga akan merugikan masyarakat sendiri.

Ekosistem Hutan Bakau sangat berperan penting terhadap kehidupan makhluk hidup. Bila keseimbangan ekosistem Hutan Bakau terganggu ataupun dengan sengaja dirusak, maka secara langsung hal tersebut akan berdampak pada kelangsungan hidup makhluk hidup, baik manusia, tumbuhan maupun hewan, sebab beberapa makhluk hidup bergantung pada ekosistem Hutan Bakau.

Selain itu, bila Hutan Bakau di alih fungsikan menjadi tambak, ekosistem Hutan Bakau terusik, secara tidak langsung akan berdampak pada ekosistem yang lain, karena ekosistem yang satu dengan yang lain saling memiliki keterkaitan atau hubungan. Disamping itu, flora fauna yang hidup dalam ekosistem tersebut dapat terganggu pertumbuhan dan perkembangannya, dan yang paling parah flora fauna tersebut punah. Bila hal itu terjadi, maka manusia pun akan merasakan dampaknya sendiri. 


\section{Sanksi Yang Dapat Dikenakan Terhadap Pelaku Pengalihfungsian Hutan Bakau menjadi Tambak}

Untuk mengetahui sanksi pidana yang dapat dikenakan kepada pelaku tindak pidana alih fungsi hutan mengrove maka dapat kita lihat dari beberapa regulasi atau peraturan yang berkaitan dengan permasalahan tersebut .Apabila alih fungsi hutan mangrove tersebut mengakibatkan perubahan terhadap kawasan suaka alam maka dapat dikenakan Pasal 40 ayat (1) Undang-Undang Nomor 5 Tahun 1990 Tentang Konservasi Sumber Daya Alam Hayati, yaitu :

"barang siapa dengan sengaja melakukan kegiatan yang dapat mengakibatkan perubahan terhadap keutuhan kawasan suaka alam dan melakukan kegiatan yang dapat mengakibatkan perubahan terhadap keutuhan zona inti taman nasional dipidana penjara paling lama 10 tahun dan denda paling banyak Rp. 200.000.000,- (Dua ratus juta rupiah)".

Perbuatan pelaku lingkungan yang dilakukan dengan kesengajaan sehingga menimbulkan kerusakan lingkungan dengan melampaui kriteria baku ukuran batas perubahan sifat fisik, kimia, dan/atau hayati lingkungan hidup yang tidak dapat ditenggang oleh lingkungan hidup. Atas tindakan perusakan lingkungan hidup yang dilakukan secara sengaja sehingga ekosistem lingkungan terganggu, oleh undang-undang lingkungan hidup dapat dikenakan berupa sanksi pidana dengan dijatuhkannya hukuman penjara.

Alihfungsi hutan bakau yang menimbulkan kerusakan hutan bakau dapat dikenakan Pasal 98 ayat (1) UndangUndang Republik Indonesia Nomor 32 tahun 2009 Tentang Perlindungan dan pengelolaan lingkungan hidup yaitu :

Setiap orang yang dengan sengaja melakukan perbuatan yang mengakibatkan dilampauinya baku mutu udara ambien, baku mutu air, baku mutu air laut, atau kriteria baku kerusakan lingkungan hidup, dipidana dengan pidana penjara paling singkat 3 (tiga) tahun dan paling lama 10 (sepuluh) tahun dan denda paling sedikit Rp3.000.000.000,00 (tiga miliar rupiah) dan paling banyak Rp10.000.000.000,00 (sepuluh miliar rupiah).

Berdasarkan Pasal 109 UndangUndang Republik Indonesia Nomor 32 tahun 2009 Tentang Perlindungan dan pengelolaan lingkungan hidup yaitu :

Setiap orang yang melakukan usaha dan/atau kegiatan tanpa memiliki izin lingkungan sebagaimana dimaksud dalam Pasal 36 ayat (1), dipidana dengan pidana penjara paling singkat 1 (satu) tahun dan paling lama 3 (tiga) tahun dan denda paling sedikit Rp1.000.000.000,00 (satu miliar 
rupiah) dan paling banyak Rp3.000.000.000,00 (tiga miliar rupiah).

Sanksi pidana dijatuhkan bagi mereka yang dengan secara sengaja melakukan perbuatan yang mengakibatkan orang luka dan/atau bahaya kesehatan manusia, sebagai akibat dilampauinya baku mutu udara ambien, baku mutu air, baku mutu air laut, atau kriteria baku kerusakan lingkungan hidup. Atau dengan sengaja melepas dan/atau mengedarkan produk rekayasa genetik ke media lingkungan hidup yang bertentangan dengan peraturan perundang-undangan atau izin lingkungan hidup yang telah diberikan oleh pemerintah.

Sanksi lain dapat pula berupa denda yakni dengan membayar sejumlah uang yang telah ditetapkan, atau dapat pula dengan dijatuhkannya sanksi administraif, berupa:

a. Teguran tertulis; sanksi ini diberikan apabila oleh pemerintah kesalahan yang dilakukan masih katagori ringan dan tahap pertama kesalahan yang dilakukan.

b. Paksaan pemerintah; apabila kesalahan terulang kembali dilakukan, maka pemerintah akan melakukan paksaan tindakan untuk dilakukannya sesuatu yang menjadi kewajiban oleh yang berbuat kesalahan.

c. Pembekuan izin

lingkungan; apabila kesalahan cukup berat dilakukan oleh pelaku lingkungan atau pelaku kegiatan sehingga berdampak terhadap pencemaran dan/atau kerusakan lingkungan hidup, maka oleh pemerintah akan melakukan pembekuan izin lingkungan dengan tenggang waktu dicairkan kembali izinnya apabila si pelaku lingkungan hidup telah melaksanakan kewajibannya.

d. pencabutaan izin lingkungan hidup; izin lingkungan hidup oleh pemerintah dicabut apabila pihak pelaku lingkungan hidup atau pelaku kegiatan sama sekali tidak mengindahkan ketentuan yang sudah ditetapkan atau telah melakukan pelanggaran berat berulangkali dan tidak ada kemauan untuk memperbaikinya.

Perusakan ekosistem hutan mangrove telah mengancam kelangsungan kehidupan masyarakat sehingga dalam rangka pencegahan dan pemberantasan perusakan hutan yang efektif dan pemberian efek jera diperlukan landasan hukum yang kuat dan yang mampu menjamin efektivitas penegakan hukum. Salah 
satunya dengan mengenakan sanksi sebagaimana Undang-Undang

Republik Indonesia Nomor 27

Tahun 2007 Tentang Pengelolaan

Wilayah Pesisir Dan Pulau-Pulau

Kecil.

\section{Pasal 73}

(1) Dipidana dengan pidana penjara paling singkat 2 (dua) tahun dan paling lama 10 (sepuluh) tahun dan pidana denda paling sedikit Rp2.000.000.000,00 (dua miliar rupiah) dan paling banyak Rp10.000.000.000,00 (sepuluh miliar rupiah) setiap Orang yang dengan sengaja:

a. melakukan kegiatan menambang terumbu karang, mengambil terumbu karang di Kawasan konservasi, menggunakan bahan peledak dan bahan beracun, dan/atau cara lain yang mengakibatkan rusaknya ekosistem terumbu karang sebagaimana dimaksud dalam Pasal 35 huruf a, huruf $b$, huruf $c$, dan huruf $\mathrm{d}$;

b. menggunakan cara dan metode yang merusak Ekosistem mangrove, melakukan konversi Ekosistem mangrove, menebang mangrove untuk kegiatan industri dan permukiman, dan/atau kegiatan lain sebagaimana dimaksud dalam Pasal 35 huruf e, huruf $f$, dan huruf g; c. menggunakan cara dan metode yang merusak padang lamun sebagaimana dimaksud dalam Pasal 35 huruf h;

d. melakukan penambangan pasir sebagaimana dimaksud dalam Pasal 35 huruf i.

e. melakukan penambangan minyak dan gas sebagaimana dimaksud dalam Pasal 35 huruf j.

f. melakukan penambangan mineral sebagaimana dimaksud dalam Pasal 35 huruf $\mathrm{k}$.

g. melakukan pembangunan fisik yang menimbulkan kerusakan sebagaimana dimaksud dalam Pasal 35 huruf 1 .

h. tidak melaksanakan mitigasi bencana di Wilayah Pesisir dan Pulau-Pulau Kecil yang diakibatkan oleh alam dan/atau Orang sehingga mengakibatkan timbulnya bencana atau dengan sengaja melakukan kegiatan yang dapat mengakibatkan terjadinya kerentanan bencana sebagaimana dimaksud dalam Pasal 59 ayat (1).

(2) Dalam hal terjadi kerusakan sebagaimana dimaksud pada ayat (1) karena kelalaian, dipidana dengan pidana penjara paling lama 5 (lima) tahun dan denda paling banyak Rp1.000.000.000,00 (satu miliar rupiah). 
Pembabatan hutan mangrove apakah untuk alihfungsi lahan menjadi tambak ataupun memanfaatkan kayunya maka dapat dikenakan Undang-Undang Nomor 18 Tahun 2013 tentang Pencegahan dan Pemberantasan Perusakan Hutan $(\mathrm{P} 3 \mathrm{H})$.

Perbuatan Pembabatan hutan mengrove di Kabupaten Kotabaru ini sebagaimana dikemukakan telah menimbulkan kerugian negara, kerusakan kehidupan sosial budaya dan lingkungan hidup, serta meningkatkan pemanasan global yang telah menjadi isu nasional, regional, dan internasional.

Pasal 82 ayat (1) Undang-Undang Republik Indonesia Nomor 18 tahun 2013 Tentang Pencegahan dan pemberantasan perusakan hutan yaitu :

Orang perseorangan yang dengan sengaja:

a. Melakukan penebangan pohon dalam kawasan hutan yang tidak sesuai dengan izin pemanfaatan hutan sebagaimana dimaksud dalam Pasal 12 huruf a;

b. Melakukan penebangan pohon dalam kawasan hutan tanpa memiliki izin yang dikeluarkan oleh pejabat yang berwenang sebagaimana dimaksud dalam Pasal 12 huruf b; dan/atau

c. melakukan penebangan pohon dalam kawasan hutan secara tidak sah sebagaimana dimaksud dalam Pasal 12 huruf c
Sanksi kepada pelaku yaitu dipidana dengan pidana penjara paling singkat 1 (satu) tahun dan paling lama 5 (lima) tahun serta pidana denda paling sedikit Rp.500.000.000,00 (lima ratus juta rupiah) dan paling banyak Rp2.500.000.000,00 (dua miliar lima ratus juta rupiah).

Dalam hal tindak pidana sebagaimana dimaksud pada ayat (1) dilakukan oleh orang perseorangan yang bertempat tinggal di dalam dan/atau di sekitar kawasan hutan, pelaku dipidana dengan pidana penjara paling singkat 3 (tiga) bulan dan paling lama 2 (dua) tahun dan/atau pidana denda paling sedikit Rp.500.000,00 (lima ratus ribu rupiah) dan paling banyak Rp500.000.000,00 (lima ratus juta rupiah).

Berdasarkan asas aturan khusus mengenyampingkan aturan yang lebih umum (lex specialis derogate legi generali) maka pengenaan sanksi atas perbuatan pengalihan fungsi hutan bakau maka Perbuatan alihfungsi hutan bakau yang merusak ekosistem dari hutan bakau tersebut dikenakan Pasal 35 huruf e Undang-Undang Republik Indonesia Nomor 27 Tahun 2007 Tentang Pengelolaan Wilayah Pesisir Dan PulauPulau Kecil. Sedangkan Perbuatan membabat hutan bakau untuk pelaku 
pembabatan hutan bakau di kenakan ketentuan pidana dalam Undang-Undang Republik Indonesia Nomor 18 tahun 2013 Tentang Pencegahan dan pemberantasan perusakan hutan.

Pada waktu membicarakan pengertian perbuatan pidana, telah dikatakan bahwa dalam istilah tersebut tidak termasuk pertanggungjawaban. Perbuatan pidana hanya menunjuk kepada dilarang dan diancamnya perbuatan dengan suatu tindak pidana. Apakah orang yang melakukan perbuatan kemudian juga dijatuhi pidana, sebagaimana telah diancamkan, ini tergantung dari soal apakah dalam melakukan perbuatan ini dia mempunyai kesalahan. Sebab azas dalam pertanggungjawaban dalam hukum pidana ialah : Tidak dipidana jika tidak ada kesalahan (Geen straf zonder schuld; Actus non facit reum nisi mens sit rea). Azas ini tidak tersebut dalam hukum tertulis tapi dalam hukum yang tak tertulis yang juga di Indonesia berlaku.

Dalam buku-buku Belanda yang pada umumnya tidak mengadakan pemisahan antara dilarangnya perbuatan dan dipidananya orang yang melakukan perbuatan tersebut (strafbaar heid van het feit/strafbaar heid van de persoon), dalam istilahnya strafbaar feit, hubungan antara perbuatan pidana dan kesalahannya dinyatakan dengan hubungan antara sifat melawan hukumnya perbuatan (wederrechtelijkheid) dan kesalahan (schuld). Dikatakan bahwa schuld tidak dapat dimengerti tanpa adanya wederrechtelijkheid, tapi sebaliknya wederrechtelijkheid mungkin ada tanpa adanya kesalahan. ${ }^{24}$

Menurut Moeljatno bahwa semua unsur-unsur kesalahan harus dihubungkan dengan perbuatan pidana yang telah dilakukan. Bahwa untuk adanya kesalahan terdakwa harus :

a. Melakukan perbuatan pidana (sifat melawan hukum)

b. Di atas umur tertentu mampu bertanggungjawab

c. Mempunyai suatu bentuk kesalahan yang berupa kesengajaan atau kealpaan

d. Tidak adanya alasan pemaaf.

Bahwa orang dapat dikatakan mempunyai kesalahan, jika dia pada waktu melakukan perbuatan pidana, dilihat dari segi masyarakat dapat dicela karenanya yaitu kenapa melakukan perbuatan yang merugikan masyarakat padahal mampu untuk mengetahui makna (jelek) perbuatan tersebut, dan karenanya dapat bahkan harus menghindari untuk berbuat demikian. Jika begitu, tentunya perbuatan tersebut memang sengaja dilakukan, dan celaannya lalu berupa : kenapa melakukan perbuatan yang dia mengerti bahwa perbuatan itu merugikan masyarakat.

\footnotetext{
${ }^{24}$ Moeljatno, Op.cit. hlm. 155
} 
Menurut M.V.T (memorie van toelicting) yang dimaksud dengan kesengajaan itu adalah meghendaki atau mengetahui (willens en wetens). Menghendaki dan mengetahui disini yaitu seseorang yang melakukan perbuatan dengan sengaja itu haruslah menghendaki apa yang ia buat, dan harus mengetahui apa pula yang ia lakukan berserta akibatnya.

Mengenai pengertian kesengajaan ini dalam teori terdapat dua paham yaitu :

\section{1) Teori Kehendak (wils-theorie )}

Teori Kehendak dikemukakan oleh Von Hippel dalam karangannya " die grenze von vor satz und fharlassighit " yang mengatakan bahwa :"Sengaja adalah kehendak membuat suatu perbuatan dan kehendak yang menimbulkan suatu akibat dari perbuatan itu, dengan kata lain sengaja itu ada apabila terjadi akibat dari suatu perbuatan yang dikehendaki itu dan boleh dikatakan bahwa akibat dikendaki apabila akibat ini menjadi maksud benar - benar dari perbuatan yang dilakukan itu ".

2) Teori Pengetahuan dan Membayangkan ( voorsteling theorie )

Pada teori pengetahuan atau membayangkan mempunyai banyak penganut, diantaranya Moeljatno, yang mengatakan bahwa : " Teori pengetahuan dari memuaskan, karena dalam kehendak dengan sendirinya diliputi pengetahuan (gambaran) tentang sesuatu itu. Lagipula kehendak merupakan arah maksud tujuan, hal mana berhubungan dengan motif ( alasan pendorong untuk berbuat ) dan tujuan dari perbuatannya".

Apabila kita kaji, para pihak yang dapat dimintai pertanggungjawaban pidana atas perusakan akibat pembabatan hutan bakau dan alihfungsi hutan bakau di Kabupaten Kotabaru ini harus memenuhi unsur kesalahan menurut hukum pidana sebagaimana dikemukakan diatas yaitu pelaku Melakukan perbuatan pidana atau secara melawan hukum melakukan perusakan, diatas umur tertentu mampu bertanggungjawab dan menginsyafi serta mengetahui akibat dari perbuatannya akan merugikan orang lain dengan bentuk kesalahan berupa kesengajaan serta tidak adanya alasan pemaaf.

Menurut Moeljatno bahwa ada kesalahan jika perbuatan yang dilakukan oleh terdakwa "verwijtbaar" (dapat dicela) dan "vermijdbaar" (dapat dihindari) (Pompe). Menurut Simons yang dikutip oleh Moeljatno bahwa kesalahan adalah adanya keadaan psyhis yang tertentu pada orang yang melakukan perbuatan pidana dan adanya hubungan antara keadaan tersebut dengan perbuatan yang dilakukan yang sedemikian rupa, hingga orang itu 
dapat dicela karena melakukan perbuatan tadi. $^{25}$

Selain penegakan hukum yang dapat dilakukan terhadap pelaku pembabatan hutan bakau di Kabupaten Kotabaru ada beberapa upaya yang dapat dilakukan untuk menanggulangi kerusakan hutan Bakau yaitu harus dilakukan pengawasan baik oleh Pemerintah Daerah khususnya Dinas Kehutanan dan Lingkungan Hidup, maupun aparat Kepolisian selain itu juga pengawasan serta penyuluhan hukum dan harus melibatkan masyarakat itu sendiri agar perusakan hutan bakau ini tidak terjadi lagi.

Selain itu, hendaknya Pemerintah Daerah Kabupaten Kotabaru memperhatikan masyarakat yang membuka areal tambak di hutan bakau apalagi di kawasan Cagar Alam melakukan upaya dengan memindahkan serta memfasilitasi pemindahan tambak-tambak tersebut di areal yang bagus untuk budidaya ikan dan udang. Selain itu memberikan penyuluhan dan pembinaan terhadap masyarakat tentang pentingnya hutan bakau sebagai penyangga tepian sungai.

\section{PENUTUP}

\section{Kesimpulan}

\section{${ }^{25}$ Ibid}

Perbuatan mengalihfungsikan hutan bakau di Kabupaten Kotabaru Provinsi Kalimantan Selatan ini merupakan tindak pidana perusakan lingkungan karena mencemarkan dan merusak lingkungan hidup disekitarnya dan tindak pidana perusakan hutan karena telah merusak hutan bakau, serta merusak ekosistem hutang bakau.

Sanksi yang dapat dikenakan kepada pelaku yang mengalihfungsikan dan bahkan melakukan pembabatan hutan bakau Di Kabupaten Kotabaru Provinsi Kalimantan Selatan yaitu dapat dikenakan Pasal 40 ayat (1) Undang-Undang Nomor 5 Tahun 1990 Tentang Konservasi Sumber Daya Alam Hayati, Undang-Undang Republik Indonesia Nomor 27 Tahun 2007 Tentang Pengelolaan Wilayah Pesisir Dan Pulau-Pulau Kecil, Pasal 98 ayat (1) Undang-Undang Republik Indonesia Nomor 32 tahun 2009 Tentang Perlindungan dan pengelolaan lingkungan hidup dan Pasal 82 ayat (1) UndangUndang Republik Indonesia Nomor 18 tahun 2013 Tentang Pencegahan dan pemberantasan perusakan hutan. Berdasarkan asas aturan khusus mengenyampingkan aturan yang lebih umum (lex specialis derogate legi generali) maka pengenaan sanksi atas perbuatan pengalihan fungsi hutan bakau maka 
Perbuatan alihfungsi hutan bakau yang merusak ekosistem dari hutan bakau tersebut dikenakan Pasal 35 huruf e Undang-Undang Republik Indonesia Nomor 27 Tahun 2007 Tentang Pengelolaan Wilayah Pesisir Dan PulauPulau Kecil. Sedangkan Perbuatan membabat hutan bakau untuk pelaku pembabatan hutan bakau di kenakan ketentuan pidana dalam Undang-Undang Republik Indonesia Nomor 18 tahun 2013 Tentang Pencegahan dan pemberantasan perusakan hutan

\section{Saran}

Hendaknya penegakan hukum harus benar-benar dilakukan secara optimal oleh aparat penegak hokum. Adapun hendaknya Pemerintah dan pihak yang berwenang melakukan upaya penyelenggaraan perlindungan pengawasan yang intensif terhadap perusakan ekosistem hutan ini agar kerusakan hutan tidak terus bertambah.

\section{DAFTAR PUSTAKA}

Abdurrahman, Pengantar Hukum Lingkungan Indonesia, Alumni, Bandung, 1983

Budi Riyanto Dan Abimanyu Pramudya Sakti, Tanpa Tahun, Kebijakan Menyikapi Perdagangan Bebas Di Sektor Kehutanan, Lembaga Pengkajian Hukum Kehutanan Dan Lingkungan, Bogor
Diantoro, Totok Dwi. 2011. "Perambahan Kawasan Hutan Pada Konservasi Taman Nasional (Studi Kasus Taman Nasional Tesso Nilo, Riau)". Mimbar Hukum. Volume 23, Nomor 3, Oktober 2011

Gatot P. Soemartono, 2012, Hukum Lingkungan Indonesia, Sinar Grafika, Jakarta

Ida Ayu Pradnya Resosudarmo, 2003, Kemana Harus Melangkah, Masyarakat Hutan Dan Perumusan Kebijakan Di Indonesia. Jakarta : Yayasan Obor Indonesia

Julian Wairata, 2010, Kerusakan Hutan Akibat Pembukaan Lahan Kebun Di Uncen Baru Waena Perumnas Iii, Makalah, Program Studi Pendidikan Geografi Jurusan Pendidikan Ilmu Pengetahuan Sosial Fakultas Keguruan Dan Ilmu Pendidikan Universitas Cenderawasih Jayapura

Moeljatno, 2000, Asas-Asas Hukum Pidana, Jakarta : Rineka Cipta

Muladi dan Barda Nawawi Arief. 1998. Teori-teori dan Kebijakan Pidana, Edisi Kedua Cetakan Kedua, Penerbit Alumni. Bandung,

Novita Inka Sari W, 2011, Makalah Ekologi Pertanian, Program Studi Agroekoteknologi,Fakultas Pertanian, Universitas Brawijaya, Malang

Paf.Lamintang, 2006, Dasar-Dasar Hukum Pidana, Jakarta : Sinar Grafika,

Riandani, 2007. Komposisi Jenis Vegetasi Mangrove di Desa Tomoli Kecamatan Ampibabo Kabupaten Parigi Moutong. Universitas Tadulako. Palu 
Soekanto, Soerjono. 2006. Sosiologi Suatu Pengantar. Jakarta: Raja Grafindo Persada.

Sudarto, 1986, Hukum Dan Hukum Pidana, Bandung,: Alumni

Suharto, 1996, Hukum Pidana Materil, Jakarta : Sinar Grafika

Wulan, Yuliana Cahya, Yurdi Yasmi, Christian Purba, dan Eva Wollenberg. 2004. Analisa Konflik Sektor Kehutanan Di Indonesia 1997-2003. Jakarta: Center for Onternational Forestry Research (CIFOR).

W.J.S Poerwadarminta, 1994, Kamus Umum Bahasa Indonesia, Balai Pustaka

Zainal Abidin Farid, 1995, Hukum Pidana, Jakarta : Sinar Grafika

Departemen Pendidikan Dan Kebudayaan, Kamus Besar Bahasa Indonesia, 1990, Jakarta: Balai Pustaka

Kementerian Lingkungan Hidup, 2004, Pengelolaan Lingkungan Hidup, Jakarta

Yanti, Nurie. 2011. Dampak Negatif Kerusakan Ekosistem Rawa. http://www.nurieyanti.blogspot.co. id/2011/06/dampak-negatifkerusakan- ekosistem-rawa.

Terminologi Hukum Inggris-Indonesia, 1996, Jakarta: Sinar Grafika

Undang-Undang Nomor 32 Tahun 2009 Tentang Perlindungan Dan Pengelolaan Lingkungan Hidup

Undang-Undang Nomor 18 Tahun 2013 Tentang Pencegahan Dan Pemberantasan Perusakan Hutan (P3H)

Undang-Undang Nomor 5 Tahun 1990 Tentang Konservasi Sumber Daya Alam Hayati.
Anonim. 2014. Suara Rakyat Untuk Presiden Baru Indonesia. Siaran Pers HuMa.

http://huma.or.id/pusatdatabase-dan-informasi/suararakyat-untuk- presiden-baruindonesia.

Endah, 2012. Kerusakan Hutan Deforestasi Di Indonesia. http://alamendah.org/2010/03/0 9/kerusakan-hutan-deforestasi-diindonesia/

Sultan, Sudirman. 2012. Strategi Penanganan Perambahan di Kawasan Konservasi. http://pengamananhutan.blogspo t.co.id/2012/05/strategipenanganan-perambahandi.html?m=1

http://sains.kompas.com/read/2011/02/2 1/1803187/Mangrove.Kalimantan .Selatan.Terancam 